\title{
POTENTIAL SIGNIFICANCE OF TRANSOVARIAL TRANSMISSION IN THE CIRCULATION OF TICK-BORNE ENCEPHALITIS VIRUS
}

\author{
Vlasta Danielová ${ }^{1}$, Jaroslava Holubová $^{1}$, Milan Pejčoch $^{2}$ and Milan Daniel ${ }^{3}$ \\ ${ }^{1}$ National Institute of Public Health, Šrobárova 48, 10042 Praha 10, Czech Republic; \\ ${ }^{2}$ Regional Public Health Institute, Kabátníkova 10, 60200 Brno, Czech Republic; \\ ${ }^{3}$ School of Public Health, Institute for Postgraduate Medical Education, Ruská 85, 10005 Praha 10, Czech Republic
}

Transovarial transmission of tick-borne encephalitis (TBE) virus in Ixodes ricinus (L., 1758), its vector tick species, has been shown both experimentally and epidemiologically to be one of the important modes of long-term virus circulation in a natural focus (Benda R. 1958: J. Hyg. Epidemiol. Microbiol. Immunol. (Prague) 2: 314-330; Řeháček J. 1962: Acta Virol. 6: 220-226; Danielová V., Holubová J. 1991: In: F. Dusbábek, V. Bukva (Eds.): Modern Acarology. Academia, Prague and SPB Academic Publishing bv, The Hague, Vol. 2, pp. 7-10). From experimental data (maternal transmission around 20\%; filial infection $0.23-0.75 \%$ ), it is possible to imagine the quantitative ratios of such transmission from one generation of ticks to another. The results cited were obtained from experiments in animals as well as in cells in vitro, i.e., only values having exceeded the infection threshold could be detected. Sub-threshold values that occur in nature appear negative, although under natural conditions they may contribute to virus circulation. The discovery of saliva-activated transmission (Nuttall P.A., Jones L.D. 1991: In: F. Dusbábek, V. Bukva (Eds.): Modern Acarology. Academia, Prague and SPB Academic Publishing bv, The Hague, Vol. 2, pp. 3-6), and non-viraemic transmission of TBE virus from infected to noninfected I. ricinus ticks during co-feeding on a host (Labuda M., Jones L.D., Williams T., Danielová V., Nuttall P.A. 1993a: J. Med. Entomol. 30: 295-299), provided novel alternative views on circulation of this virus in nature that call for further observation of what degree larvae participate in circulation of the virus. In identifying conditions for the existence of natural foci (Randolph S.E., Miklisová D., Lysý J., Rogers D.J., Labuda M. 1999: Parasitology 118: 177-186; Labuda M., Randolph S.E. 1999: Zentralbl. Bakteriol. 289: 513-524), the authors propose that a fundamental condition for the existence of a natural focus is the synchronisation of aggregation in the co-feeding of larvae and nymphs. Thus under the precondition that virus is transmitted from nymphs to uninfected larvae, only the spring season is considered to be important. Feeding in the autumn season is considered unimportant, as is transovarial transmission. These hypotheses are the basis for consideration in further papers (Randolph S.E. 2000: Adv. Parasitol. 47: 217-243; Randolph S.E., Green R.M., Peacey M.F., Rogers D.J. 2000: Parasitology 121: 1523; Randolph S.E. 2001: Philos. Trans. R. Soc. Lond. B 356: 1045-1056), hence we wished to test through experiments in nature, the degree and manner in which larvae participate in virus circulation. In localities of the South Bohemian natural focus of TBE (Czech Republic) where, in the preceding year,
TBE virus was repeatedly isolated from tick nymphs and imagoes, we trapped small terrestrial mammals for serological investigations and for ticks that were investigated for the presence of TBE virus. Most of the ticks were I. ricinus larvae, the other developmental stages being represented in negligible numbers.

Small terrestrial mammals were trapped in two periods, May 22-25 and October 2-5, 2001, in selected localities and habitats where ticks had been collected by flagging and investigated the year before (Danielová V., Holubová J., Daniel M. 2002: Exp. Appl. Acarol. 26, in press).

Small mammals were live-trapped in bridge metal traps, in each collecting site, for two consecutive nights. All parasites were collected from each animal individually; ticks were selected from the material, identified, counted and cooled. Trapping occurred in the area within $48^{\circ} 44^{\prime}-48^{\circ} 54^{\prime} \mathrm{N}$ and $14^{\circ} 29^{\prime}-14^{\circ} 35^{\prime} \mathrm{E}$ in the localities of Borovany (border zone between tall mixed woods [oak, pine, spruce] and stand of young oak trees), Kaplice (small isolated deciduous wood stands [oak, birch, lime trees and shrubs of Corylus avellana] surrounded by cornfields), and Rímov (ravine in mixed wood, bottom covered by abundant herb layer).

Ixodes ricinus ticks (mostly larvae), after removal from hosts were cooled thus they were live before processing. The ticks were investigated in virus isolation experiments using the porcine cell culture, PS, and examined by indirect immunofluorescence (IIF).

Larvae removed from each host were processed separately in numbers of 1 to 61 . In cases where they were also present, nymphs or a female were processed individually. Irrespective of their numbers, each batch of ticks was triturated in $1 \mathrm{ml}$ Leibovitz medium L-15 supplemented with 3\% bovine serum, $200 \mu \mathrm{g}$ gentamycin and $2.5 \mu \mathrm{g}$ amphotericin B. After incubation for $1.5 \mathrm{~h}$ at $4^{\circ} \mathrm{C}$ the suspension was centrifuged 15 min at $5000 \mathrm{rpm}$, and $0.1 \mathrm{ml}$ supernate inoculated onto two incubation chamber slides for the IIF test and into two wells of a 96-well plate for further passaging; the third passage was carried out on cover slips in Leighton tubes for another IIF test. Additionally, in the first passage a plaque assay was carried out $(0.2 \mathrm{ml}$ in a 24 -well plate) as previously described (Danielová et al. 2002, op. cit.).

In the spring season, 27 small mammals were trapped, ticks being found on 18 of them; in the autumn season, 76 small mammals were trapped, 29 of which were parasitised by ticks. Species composition was the following: Apodemus flavicollis (Melchior), A. sylvaticus (Linnaeus), Clethrionomys glareolus 
Table 1. List of trapped mammalian species, prevalence and intensity of tick infestation, and TBE virus isolation.

\begin{tabular}{|c|c|c|c|c|c|c|c|}
\hline $\begin{array}{l}\text { Date of } \\
\text { trapping }\end{array}$ & Mammal species & Sex & No. trapped & $\begin{array}{l}\text { No. tick- } \\
\text { infested }\end{array}$ & No. ticks & $\begin{array}{c}\text { Mean intensity } \\
\text { of infestation }\end{array}$ & $\begin{array}{l}\mathrm{TBE} \\
\text { virus }\end{array}$ \\
\hline \multirow{10}{*}{ 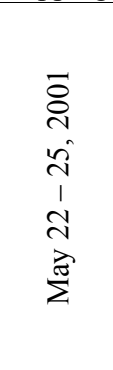 } & Clethrionomys & $\mathrm{F}$ & 5 & 3 & $22 \mathrm{~L}$ & 7.3 & \\
\hline & glareolus & M & 7 & 3 & $34 \mathrm{~L}$ & 11.3 & \\
\hline & Anodomus siluaticus & $\mathrm{F}$ & 5 & 5 & $86 \mathrm{~L}+1 \mathrm{~F}$ & 17.4 & \\
\hline & Aponemus sytualcus & $\mathrm{M}$ & 3 & 3 & $76 \mathrm{~L}+1 \mathrm{~N}$ & 25.7 & \\
\hline & Apodemus sp. & M & 1 & 1 & $19 \mathrm{~L}$ & 19.0 & \\
\hline & Microtus agrestis & M & 1 & 0 & & & \\
\hline & Pitymys subterraneus & $\mathrm{F}$ & 2 & 0 & & & \\
\hline & Soror aranous & $\mathrm{F}$ & 1 & 1 & $17 \mathrm{~L}$ & 17.0 & \\
\hline & sorex araneus & M & 2 & 2 & $6 \mathrm{~L}$ & 3.0 & 1 \\
\hline & Total & & 27 & 18 & $260 \mathrm{~L}+1 \mathrm{~N}+1 \mathrm{~F}$ & 14.6 & 1 \\
\hline \multirow{13}{*}{ 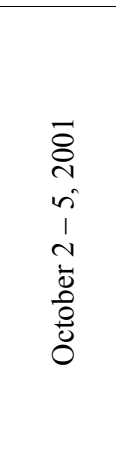 } & Clethrionomys & $\mathrm{F}$ & 11 & 2 & $2 \mathrm{~L}$ & 1.0 & \\
\hline & glareolus & M & 15 & 3 & $6 \mathrm{~L}$ & 2.0 & 1 \\
\hline & Anodomus soluaticus & $\mathrm{F}$ & 5 & 3 & $14 \mathrm{~L}+1 \mathrm{~N}$ & 3.0 & \\
\hline & Ароаети sylvallcus & M & 1 & 0 & & & \\
\hline & Anodemus flavicollis & $\mathrm{F}$ & 5 & 2 & $11 \mathrm{~L}$ & 5.5 & \\
\hline & Ароаетия лla1 & M & 13 & 9 & $95 \mathrm{~L}+1 \mathrm{~N}$ & 10.7 & \\
\hline & Anodemus sr & $\mathrm{F}$ & 7 & 3 & $4 \mathrm{~L}$ & 1.3 & 1 \\
\hline & Ародетиз sp. & M & 5 & 2 & $12 \mathrm{~L}$ & 6.0 & \\
\hline & Microtus arval & $\mathrm{F}$ & 3 & 1 & $1 \mathrm{~L}$ & 1.0 & \\
\hline & Microtus arvalis & M & 5 & 1 & $2 \mathrm{~L}$ & 2.0 & \\
\hline & Pitymys subterraneus & $\mathrm{F}$ & 2 & 2 & $11 \mathrm{~L}$ & 5.5 & \\
\hline & Sorex araneus & M & 4 & 1 & $1 \mathrm{~L}$ & 1.0 & \\
\hline & Total & & 76 & 29 & $159 \mathrm{~L}+2 \mathrm{~N}$ & 5.6 & 2 \\
\hline
\end{tabular}

$\mathrm{F}$ - female, $\mathrm{L}$ - larva, $\mathrm{M}$ - male, $\mathrm{N}$ - nymph

(Schreber), Microtus arvalis (Pallas), M. agrestis (Linnaeus), Pitymys subterraneus (de Sélys-Longchamps), and Sorex araneus Linnaeus. Numbers of mammals trapped, their tick infestation levels, and results of virological examinations are presented in Table 1.

In the spring season, 260 larvae in various stages of feeding were investigated in pools of 1 to 61 (18 batches) as well as one half-fed female tick co-feeding with 6 well-fed larvae on a gravid Apodemus sylvaticus female, and one nymph cofeeding with 10 larvae on an adult male of the same species.

In the autumn season, 159 larvae were examined in pools of 1 to 43 (29 batches) as well as two nymphs, one co-feeding with 5 larvae on an adult Apodemus sylvaticus female, and the other co-feeding with 10 larvae on a juvenile Apodemus flavicollis male.

TBE virus was demonstrated in three samples: No. 483 from 3 larvae having no trace of blood, removed from an adult Sorex araneus male trapped on May 25 at Kaplice; No. 734 from 2 larvae one of which was fully fed and the other was unfed, removed from a juvenile Clethrionomys glareolus male trapped on October 4 in the locality of Borovany; and No. 739 from one fed larva removed from a juvenile Apodemus sp. female trapped on October 4 at Kaplice. The virus was detected in relatively small amounts, forming small islets of infected cells. In one case TBE virus was detected on primary inoculation whereas in two cases the virus was only detected in the third passage. In all cases immunofluorescence was detected in less than $10 \%$ of the monolayer. Sera of the hosts of ticks comprising samples No. 734 and No. 739 were negative for TBE virus both on virological and serological examination; the third host was dead and did not yield blood.
Larvae having co-fed with one nymph (three examples) and with one female (one example) were negative for the virus.

The overall infestation level in the spring reached $67 \%$ and in the autumn, $38 \%$; the mean intensity of infestation was 14.6 (range 3.0-25.7) and 5.6 (range 1.0-10.7) ticks per infested host, respectively.

The results do not support the contention of some authors that persistent circulation of TBE virus can be achieved only where infected nymphs feed on rodents alongside large numbers of infectable larvae, particularly in spring. On the contrary, our results point to the importance of mass co-feeding of larvae alone, both in spring and autumn.

Although the intensity and prevalence of infestation in small mammals was lower in the autumn than in spring, as is the usual case, the number of feeding ticks was such that it cannot be ignored in considerations regarding the existence of natural foci of TBE. However, it has been postulated that only the spring generation contributes significantly to the existence of natural foci (Randolph et al. 1999, op. cit.). Similarly our results do not correspond with the claim that the spring cofeeding of nymphs with larvae is the main base for TBE natural focus existence.

In both the spring and autumn seasons, co-feeding of nymphs with larvae was comparatively infrequent and all three nymphs examined were found to be negative in virus isolation experiments.

Although the sample size was small, no evidence was found to support the hypothesis that non-viraemic transmission is brought about only in the direction nymphs to larvae (particularly as the sole condition for the existence of natural foci of infection) as cited in the introduction (Randolph et al. 
1999, op. cit.; Labuda and Randolph 1999, op. cit.; Randolph 2000, op. cit.). Amplification of TBE virus during co-feeding of larvae was postulated on the basis of laboratory experiments by Labuda et al. (Labuda M., Danielová V., Jones L.D., Nuttall P.A. 1993b: Med. Vet. Entomol. 7: 339-342). The cofeeding of larvae in nature is much more frequent than that of larvae with nymphs, and is consistent with field data showing that larvae mostly feed on small terrestrial mammals while nymphs feed on medium-size mammals and birds (Rosický B. 1954: Acta Soc. Zool. Bohemoslov. 18: 41-70). Thus, cofeeding of larvae may contribute to a significant degree in the maintenance of TBE virus foci, and points to the potential importance of infection at this developmental stage by TBE virus. In the comparatively exceptional co-feeding of nymphs with larvae, the relatively low infection rate of nymphs means that the probability of transmission from nymphs to larvae is small. The average virus prevalence in nymphs found in the studied area was only $0.37 \%$ in 2000 (Danielová et al. 2000, op. cit.), and $0.15 \%$ in the Czech Republic for 1970-1999 according to Januška (Januška J. 1999: Results of virological investigations of ticks from the Czech Republic tested in the National Reference Laboratory for Arboviruses in 1970-1999; unpubl. document).
Results of TBE virus isolations from larvae (particularly those found in the fur of small mammals that had not yet fed) support the occurrence of transovarial transmission of TBE virus. Such infections have the potential to spread further among larvae by co-feeding and consequently could be transstadially transmitted to nymphs.

Our results were obtained in a highly active natural focus of TBE in Southern Bohemia, which manifests itself by continually high numbers of human cases of disease; accordingly, under such conditions there can be no doubt there persists a stabilized long-term circulation of TBE virus ensured by Ixodes ricinus ticks. Although the sample sizes are comparatively small, the data do not support the proposed sine qua non condition for the existence of natural foci of TBE (Randolph et al. 1999, op. cit.) and hence question deductions based on this tenet (Randolph et al. 2000, op. cit.; Randolph S.E., Rogers D.J. 2000: Proc. R. Soc. Lond. B 267: 17411744; Randolph 2001, op. cit.).

Acknowledgement. The research presented in this paper was funded in part by the project Climate Change Adaptation Strategies for Human Health (cCASHh), Contract No. EVK22000-00670.

Accepted 24 June 2002 